ABDI: Jurnal Pengabdian dan Pemberdayaan Masyarakat ISSN: 2656-369X (Print), 2684-8570 (Online)

Volume 3 No. 1, Juni 2021

http://abdi.ppj.unp.ac.id/index.php/abdi

Email: abdi@ppj.unp.ac.id

DOI: https://doi.org/10.24036/abdi.v3il.66

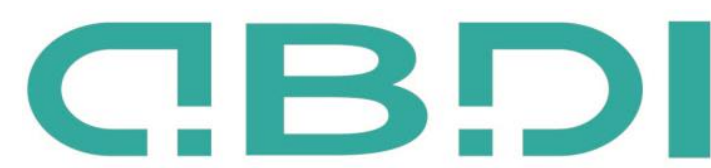

ABDI: JURNAL PENGABDIAN DAN PEMBERDAYAAN MASYARAKAT

\title{
Sistem Penilaian Kinerja dan Penentuan Insentif di CV Sense of Life Group
}

\section{Melati Kurniawati ${ }^{1}$, Yoanita Yuniati ${ }^{2}$, Lauditta Irianti ${ }^{3}$, Yanti Helianty ${ }^{4}$, Abu Bakar ${ }^{5}$ Amir Rudiana ${ }^{6}$}

\author{
1,2,3,4,5,6 Prodi Teknik Industri, Fakultas Teknologi Industri, Institut Teknologi Nasional Bandung
}

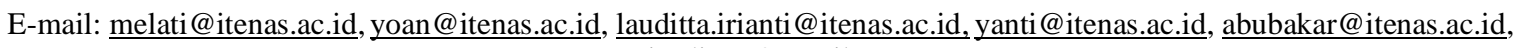
amirudiana@gmail.com

Abstrak
Permasalahan tenaga kerja akan menjadi masalah yang besar di suatu perusahaan, sehingga butuh ilmu manajemen dalam menanganinya. Salah satu bidang manajemen sumberdaya manusia adalah pengukuran kinerja dan pemberian insentif karyawan. CV Sense of Life Group berupaya untuk meningkatkan motivasi kerja operator melalui penerapan sistem manajemen kinerja dan pemberian insentif. Sistem kompensasi yang diterapkan saat ini masih bersifat subjektif dan diduga belum dapat meningkatkan kinerja operatornya. Oleh karena itu, tim pengabdian masyarakat mencoba menerapkan manajemen kinerja dengan membuat alat ukur kinerja, mengukur kinerja dan memberikan rincian insentif yang dapat dijadikan acuan perusahaan. Alat ukur kinerja dibuat dengan pendekatan metode AHP, visualisasi pengukuran kinerja dibantu oleh Microsoft Excel dan insentif diberikan per bulan dengan dasar rank hasil kinerja.

Kata kunci: Insentif; Pengukuran kinerja operator; Sumber daya manusia.

\section{Abstract}

Manpower problems will be a big problem in a company, so it requires management knowledge to handle it. One of the areas of human resource management is measuring performance and providing employee incentives. CV Sense of Life Group seeks to increase operator motivation through the implementation of a performance management system and the provision of incentives. The current compensation system is still subjective in nature and is thought to have not been able to improve the operator's performance. Therefore, the community service team tried to implement performance management by making performance measurement tools, measuring performance and providing details of incentives that can be used as company references. Performance measurement tools are made using the AHP method approach, visualization of performance measurements is assisted by Microsoft Excel and incentives are given per month on the basis of rank performance results.

Keyword: Incentives; Operator performance measurement; Human resources.

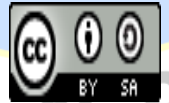

Received: 16 November $2020 \quad$ Revised: 19 Maret $2021 \quad$ Available Online: 22 Maret 2021




\section{Pendahuluan}

Perusahaan akan berjalan dengan baik bila dapat mengelola faktor internal dan eksternal secara tepat. Salah satu faktor internal perusahaan yang penting adalah sumber daya manusia atau tenaga kerja. Pengertian tenaga kerja menurut undang-undang Republik Indonesia adalah "setiap orang yang mampu melakukan pekerjaan guna menghasilkan barang atau jasa untuk memenuhi kebutuhan sendiri atau kebutuhan masyarakat" (Undang-undang RI No.13 Tahun 2003). Dapat disimpulkan bahwa tenaga kerja adalah semua orang yang bersedia dan sanggup bekerja, termasuk mereka yang menganggur meskipun bersedia dan sanggup bekerja dan mereka yang menganggur terpaksa akibat tidak ada kesempatan kerja.

Masalah ketenagakerjaan merupakan masalah umum dan mendasar yang dihadapi oleh hampir semua negara di dunia, antara lain terkait dengan masalah kesempatan kerja serta tingkat upah yang rendah dan produktivitas yang rendah. Masalah ini juga merupakan masalah kompleks yang didalamnya mengandung dimensi ekonomis, sosial, kesejahteraan dan sosial politik (Wijayanto, 2019).

Manajemen Sumber Daya Manusia (MSDM) merupakan suatu ilmu atau cara untuk mengelola hubungan dan peranan sumber daya (tenaga kerja) yang dimiliki oleh individu secara efisien dan efektif serta dapat digunakan secara maksimal sehingga tercapai tujuan perusahaan. MSDM juga menyangkut desain dan implementasi sistem perencanaan, penyusunan karyawan, pengembangan karyawan, pengelolaan karier, evaluasi kerja, kompensasi karyawan dan hubungan ketenagakerjaan baik karyawan maupun masyarakat sekitar (Setiani, 2013). Pentingnya pengelolaan sumber daya manusia ini, perlu disadari oleh semua tingkatan manajemen. Bahkan saat ini dimana kemajuan teknologi melaju sangat pesat namun tidak menurunkan tingkat kepentingan faktor manusia dalam keberhasilan suatu organisasi. MSDM menjadi solusi untuk menghindari dan meminimalisir terjadinya masalah dalam mengelola tenaga kerja di perusahaan.

CV Sense of Life Group merupakan salah satu perusahaan yang bergerak dibidang teknisi, manufaktur serta konsultan yang bertempat di Kampus POLMAN (Politeknik Manufaktur) tepatnya di Jl. Kanayakan No.21, Dago, Kecamatan Coblong, Kota Bandung, Jawa Barat. Perusahaan tersebut berdiri sejak tahun 2010 dan pada tahun 2015 perusahaan tersebut memindahkan produksi ke Small Scale Manufacture Laboratory (SSML) yang berlokasi di gedung 10 Itenas Bandung. CV. Sense of Life Group memproduksi berbagai macam produk sesuai pesanan pelanggan/konsumen seperti pembuatan alat pakan ikan dan alat pelontar bola tenis. Sistem produksi pada perusahaan ini adalah make to order yang artinya perusahaan akan membuat produk ketika ada pesanan masuk.

CV Sense of Life Group memiliki 7 orang pekerja yang terdiri dari satu orang manager produksi, satu orang administrasi, satu orang kepala bengkel, satu orang engineering programmer dan 3 orang operator. Perusahaan ini menerapkan 2 shift kerja dimana jadwal dapat berubah tergantung kondisi pemesanan dan banyaknya pesanan. Pada kondisi normal terdapat 3 orang dan kepala bengkel yang bekerja dalam kondisi 2 shift kerja, akan tetapi jika kondisi sibuk (pesanan melebihi kapasitas) maka seluruh pegawai turut dalam pembagian shift, baik itu pagi maupun malam. Permasalahan yang sering dikeluhkan oleh pegawai adalah kompensasi yang diberikan dirasakan tidak sesuai dengan kewajiban yang dilakukan oleh pegawai. Saat ini, kebijakan perusahaan dalam menentukan kompensasi masih berdasarkan penilaian subjektivitas pemimpin perusahaan dan belum menerapkan pengukuran kinerja.

Kinerja diartikan sebagai indikator keberhasilan personal, tim, atau unit organisasi dalam mewujudkan sasaran yang telah ditetapkan oleh organisasi dalam mewujudkan sasaran yang telah diterapkan oleh organisasi dengan prilaku yang diharapkan (Baharun, 2016). Kinerja perlu dikelola dengan konsep manajemen kinerja berupa proses menciptakan pengertian tentang apa yang harus dilakukan, cara mencapainya dan suatu pendekatan mengelola manusia untuk meningkatkan kemungkinan pencapaian hasil yang berhubungan dengan pekerjaan. Dalam manajemen kinerja terdapat tiga fase yaitu perencanaan kinerja, pembinaan kinerja dan Evaluasi atau penilaian kinerja (Baharun, 2016).

Penilaian kinerja adalah kegiatan manajer untuk mengevaluasi perilaku prestasi kerja pegawai serta menetapkan kebijakan selanjutnya (M. S. Hasibuan, 2002). Tujuan penilaian kinerja pada

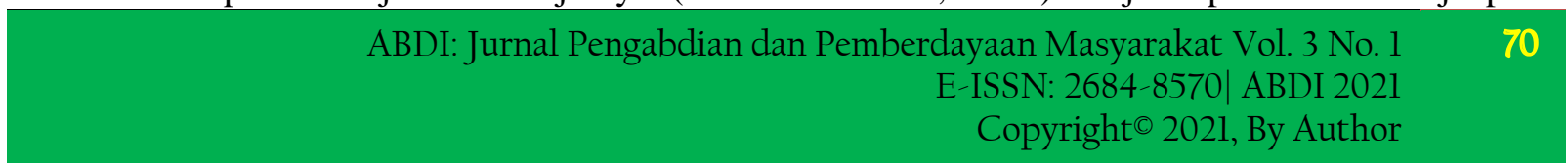


dasarnya meliputi: (1) Mengetahui tingkat prestasi karyawan selama ini; (2) Pemberian imbalan yang serasi, misalnya untuk pemberian kenaikan gaji berkala, gaji pokok, kenaikan gaji istimewa, insentif uang; (3) Mendorong pertanggung jawaban dari karyawan; (4) Untuk pembeda antakaryawan yang satu dengan yang lainnya; (5) Pengembangan SDM yang masih dapat dibedakan lagi kedalam:penugasan kembali, promosi, kenaikan jabatan, dan training atau Latihan; (6) Meningkatkan motivasi kerja; (7) Meningkatkan etos kerja; (8) Memperkuat hubungan antara karyawan dengan supervisor melalui diskusi tentang kemajuan kerja mereka.

Penilaian kinerja dapat digunakan sebagai dasar pemberian kompensasi pegawai. Kompensasi adalah keseluruhan balas jasa yang diterima pegawai sebagai akibat dari pelaksanaan pekerjaan di organisasi (Suwati, 2013). Kompensasi dapat berupa gaji, upah, bonus, insentif dan tunjangan (Kesehatan, hari raya, uang makan uang cuti). Kompensasi dibagi menjadi dua yaitu kompensasi langsung dan tak langsung. Kompensasi tidak langsung adalah kompensasi yang diterima oleh karyawan yang tidak mempunyai hubungan secara langsung dengan pekerjaanya antara lain, asuransi kesehatan, uang pensiun, pakaian dinas, kafetaria, mushola, olahraga, darmawisata. Kompensasi tidak langsung dapat berupa benefit servis dari perusahaan yang diberikan berdasarkan kebijakan perusahaan terhadap semua karyawan dalam usaha meningkatkan kesejahteraan mereka (M. S. Hasibuan, 2002).

Tujuan utama setiap organisasi merancang sistem kompensasi adalah untuk memotivasi karyawan dalam rangka meningkatkan kinerjanya dan mempertahankan karyawan yang kompeten bertahan diperusahan. George (2013) menyatakan bahwa motivasi dapat diartikan sebagai suatu upaya agar seseorang dapat menyelesaikan pekerjaan dengan semangat, dân karenan keinginannya untuk melaksanakannya. Pemberian kompensasi yang sesuai dengan kinerja karyawan diharapkan dapat menyebabkan karyawan memiliki komitmen, dan karyawan tersebut termotivasi untuk meningkatkan kinerjanya demi keberhasilan dan kemajuan perusahaan dalam mencapai tujuannya (Moheriono, 2009).

Pemberian upah yang adil dan benar kepada karyawan merupakan hal yang sangat penting bagi perusahaan dan karyawan. Perusahaan akan mendapatkan karyawan yang bersedia bekerja dan menjalankan tugas-tugasnya dengan baik, sedangkan karyawan merasa pemberian upah tersebut sebagai penghargaan atas kerja yang telah dilaksanakan. Upah sendiri bisa dikatakan sebagai imbalan langsung yang berupa uang dan diberikan kepada karyawan atas hasil kerjanya yang dapat diukur dengan satuan tertentu (jumlah unit barang yang dihasilkan atau masa atas jasa pekerjaan yang diserahkan). Skala upah disini yaitu kesetaran besaran upah kepada masing-masing karyawan untuk pekerjaan yang sama. Jika ketiga hal tersebut diberikan secara benar kepada karyawan, maka tujuan perusahaan akan cepat tercapai.

Tujuan pemberian upah oleh perusahaan adalah untuk ikatan kerja sama, kepuasan kerja, motivasi kerja dan disipilin. Salah satunya yaitu untuk memotivasi karyawan dalam bekerja, dimana pemberian upah yang adil dan benar akan meningkatkan motivasi kerja karyawan sehingga merangsang karyawan untuk bekerja dengan giat. Sebaliknya, jika pemberian upah tidak benar, maka dapat menurunkan motivasi kerja karyawan. Seperti yang dikatakan oleh Hasibuan (2016) bahwa, "setiap manusia/karyawan mengharapkan kompensasi (gaji/upah) dari prestasi yang diberikannya dalam mendukung faktor motivasi kerja" (M. Hasibuan, 2016).

Sarana motivasi lainnya yang mendorong para karyawan untuk bekerja dengan kemampuan yang optimal adalah pemberian insentif. Insentif adalah pendapatan ekstra di luar gaji atau upah yang telah ditentukan. Insentif merupakan suatu faktor pendorong bagi karyawan untuk bekerja lebih baik agar kinerja karyawan dapat meningkat. Insentif adalah suatu bentuk motives' yang dinyatakan dalam bentuk uang atas dasar kinerja yang tinggi dan juga merupakan rasa pengakuan dari pihak organisasi terhadap kinerja karyawan dan kontribusi terhadap organisasi (perusahaan) (Mangkunegara, 2013).

Terdapat dua jenis insentif yang umum diberikan antara lain insentif finansial (berupa uang) dan insentif nonfinansial (berupa penghargaan, promosi jabatan, dan lain-lain) (Yavuz, 2004). Pemberian insentif finansial cenderung memiliki pengaruh yang lebih besar dibandingkan dengan 
insentif nonfinansial, karena dampaknya yang langsung dapat dirasakan. Tetapi, hasil penelitian menunjukkan bahwa pada tingkat kebutuhan tertentu peningkatan pendapatan tidak akan lagi meningkatkan motivasi pekerja karena tidak dapat memenuhi kebutuhan yang dimiliki oleh pekerja tersebut. Dalam kondisi ini insentif nonfinansial akan lebih meningkatkan motivasi dan performansi kerja.

Kegiatan pengabdian kepada masyarakat ini bertujuan untuk membantu upaya peningkatan kinerja para operator di CV Sense of Life Group, dengan mengimplementasikan pendekatan manajemen kinerja dan simulasi pemberian insentif. Adapun isi dari laporan pengabdian masyarakat ini terdiri dari latar belakang dari perusahaan dan literature terkait permasalahan, metode pelaksanaan dari kegiatan, hasil pembahasan serta kesimpulan.

\section{Metode Pelaksanaan}

Metode pelaksanaan pengabdian masyarakat ini dibagi menjadi 6 kegiatan. Kegiatan dimulai dari Melakukan identifikasi masalah, Studi literatur, Perancangan sistem kinerja, Aplikasi sistem kinerja, Analisis dan Evaluasi.

\subsection{Identifikasi Masalah}

Pada kegiatan ini dilakukan koordinasi dengan pemimpin perusahaan untuk mencari permasalahan yang terjadi. Dari hasil wawancara didapatkan bahwa saat ini perusahaan belum memiliki sistem kinerja yang objektif. Dokumentasi saat pengambilan data wawancara dapat dilihat pada Gambar 1.

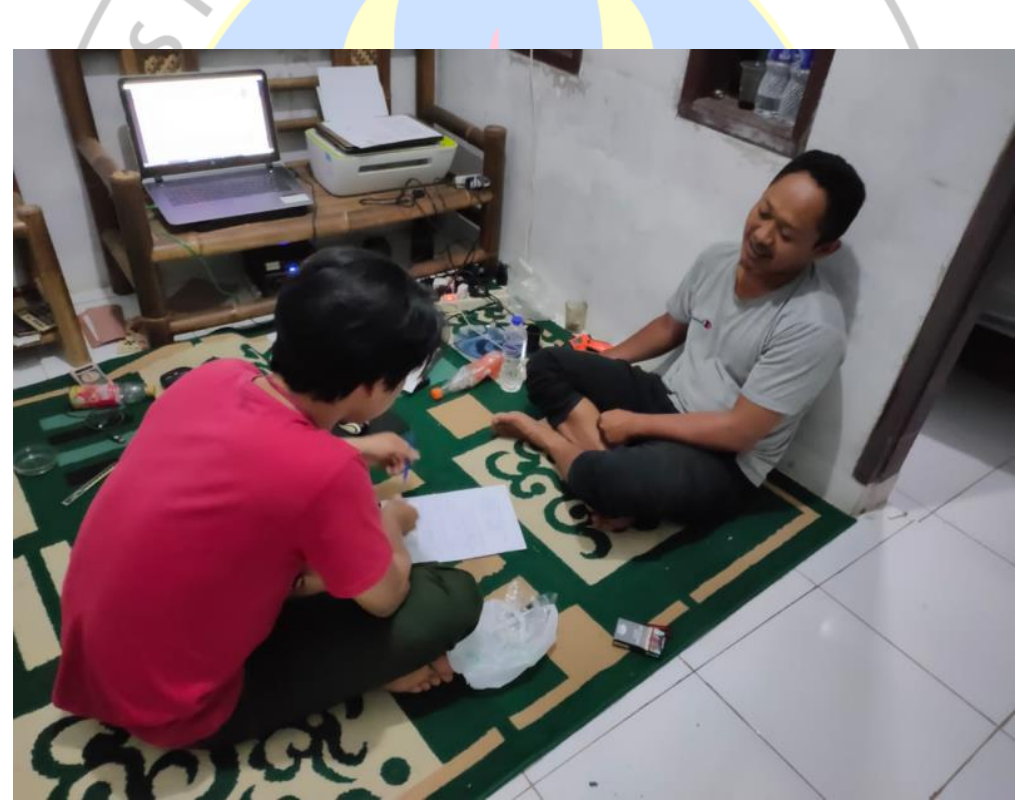

Gambar 1. Proses Wawancara dengan Pemimpin CV Sense of Life Group

\subsection{Studi Literatur}

Pada kegiatan studi literatur tim pengabdian masyarakat mencari referensi yang sesuai dengan permasalahan pada CV Sense of Life. Literatur yang terkait dengan kegiatan pengabdian masyarakat adalah Tenaga Kerja, Manajemen Sumber Daya Manusia, Kompensasi, Upah, Insentif, Penilaian Kinerja dan Metode AHP.

\subsection{Perancangan Sistem Kinerja}

Setelah mendapatkan literatur sebagai dasar pembuatan sistem kinerja maka dimulailah perancangan sistem kinerja. Urutan perancangan dimulai dari merancang kuesioner, penyusunan

$$
\begin{array}{r}
\text { ABDI: Jurnal Pengabdian dan Pemberdayaan Masyarakat Vol. } 3 \text { No. } 1 \\
\text { E-ISSN: 2684-8570| ABDI } 2021 \\
\text { Copyright }{ }^{\complement 2021} \text {, By Author }
\end{array}
$$


struktur hirarki, pembuatan matriks perbandingan, perhitungan nilai eigen vektor, penentuan nilai eigen maksimal, perhitungan indeks konsistensi, Perhitungan rasio konsistensi dan penentuan penilaian kinerja pegawai.

\subsection{Aplikasi Sistem Kinerja}

Tahap selanjutnya adalah mengaplikasikan sistem yang telah dibuat. Tahapan ini terdiri dari pembuatan form penilaian karyawan, pemberian nilai karyawan kepada pemimpin perusahaan dan rekapitulasi hasil perhitungan nilai kinerja tiap pegawai.

\subsection{Analisis}

Pada tahap ini dilakukan analisis perbandingan sistem antara sebelum dan setelah dilakukan implementasi sitem kinerja. Dilihat dari kompensasi berupa pendapatan setiap karyawan.

\subsection{Evaluasi}

Dalam kegiatan ini dilakukan diskusi antara tim pengabdian masyarakat dengan pimpinan perusahaan. Diskusi dilakukan untuk membahas sistem kinerja terkait dengan kelebihan dan kekurangan sistem tersebut.

\section{Hasil dan Pembahasan}

Identifikasi awal didapat dari hasil kunjungan ke perusahaan untuk melihat lingkungan kerja karyawan. Kegiatan identifikasi ini dimulai tanggal 3 Februari 2020. Hasil dari identifikasi awal menunjukkan bahwa perusahaan belum memiliki sistem penilaian kinerja yang sistematik. Pemberian insentif masih berdasarkan penilaian subjektif pemimpin perusahaan. Sistem ini menimbulkan permasalahaan, yaitu merasa adanya ketidakadilan karena tidak ada perbedaan antara operator yang bekerja lebih dengan yang biasa saja. Hal ini yang membuat tim pengabdian masyarakat mengambil tindakan untuk bekerja sama dalam menerapkan sistem penilaian kinerja dan insentif di CV Sense of Life.

\section{Tabel 1. Variabel dan Bobot Penilaian Kinerja}

\begin{tabular}{|c|c|c|c|c|}
\hline Kriteria & $\begin{array}{l}\text { Bobot } \\
\text { Lokal }\end{array}$ & Sub Kriteria & $\begin{array}{l}\text { Bobot } \\
\text { Lokal }\end{array}$ & $\begin{array}{l}\text { Bobot } \\
\text { Global }\end{array}$ \\
\hline \multirow{2}{*}{ Kualitas Kerja } & \multirow{2}{*}{0.394} & Ketepatan Hasil Kerja & 0.666 & 0.262 \\
\hline & & Ketelitian Kerja & 0.333 & 0.131 \\
\hline \multirow[b]{2}{*}{ Kedisiplinan } & \multirow[b]{2}{*}{0.353} & Kehadiran & 0.750 & 0.265 \\
\hline & & $\begin{array}{c}\text { Ketaatan pada peraturan } \\
\text { perusahaan }\end{array}$ & 0.250 & 0.088 \\
\hline \multirow{2}{*}{ Ketepatan Waktu } & \multirow{2}{*}{0.161} & Kecepatan Waktu Kerja & 0.750 & 0.120 \\
\hline & & Kedisiplinan Kerja & 0.250 & 0.040 \\
\hline \multirow{2}{*}{$\begin{array}{c}\text { Dampak } \\
\text { Interpersonal }\end{array}$} & \multirow{2}{*}{0.092} & Bekerja Sama & 0.750 & 0.069 \\
\hline & & Komunikasi & 0.250 & 0.023 \\
\hline
\end{tabular}

Kinerja adalah hasil kerja yang telah diperoleh individu berdasarkan syarat pekerjaan tersebut. Dalam menentukan kinerja yang baik perusahaan harus memiliki standar pekerjaan yang telah diputuskan bersama. Untuk mendapatkan nilai kinerja terlebih dahulu perlu ditentukan variabelvariabel yang dapat mengukur hasil kerja operator (Suhardoyo, 2018). Variabel yang digunakan dalam memutuskan kinerja operator perusahaan ini berasal dari penelitian yaitu kualitas kerja, kuantitas kerja, kedisiplinan, ketepatan waktu dan dampak interpersonal. Variabel tersebut dipilih karena terdapat kesesuaian dengan output yang diharapkan perusahaan dari operator. Setelah mendapatkan variabel yang digunakan untuk mengukur kemudian dilakukan pembobotan setiap 
variabel agar diketahui variabel yang lebih penting dalam penilaian. Pembobotan variabel dilakukan dengan pendekatan metode AHP. Hasil dari pembobotan tersebut dapat dilihat pada Tabel 1.

Tahapan yang dilakukan setelah menentukan variabel dan pembobotan adalah melakukan visualisasi dari sistem tersebut. Pembuatan visualisasi tersebut dibantu dengan software Microsoft Excel. Visualisasi ini dimaksudkan untuk mempermudah user (pimpinan perusahaan) dalam memasukkan data dan menentukan nilai kinerja tiap operator berdasarkan hasil kerjanya. Visualisasi sistem penilaian kinerja dapat dilihat pada Gambar 2.

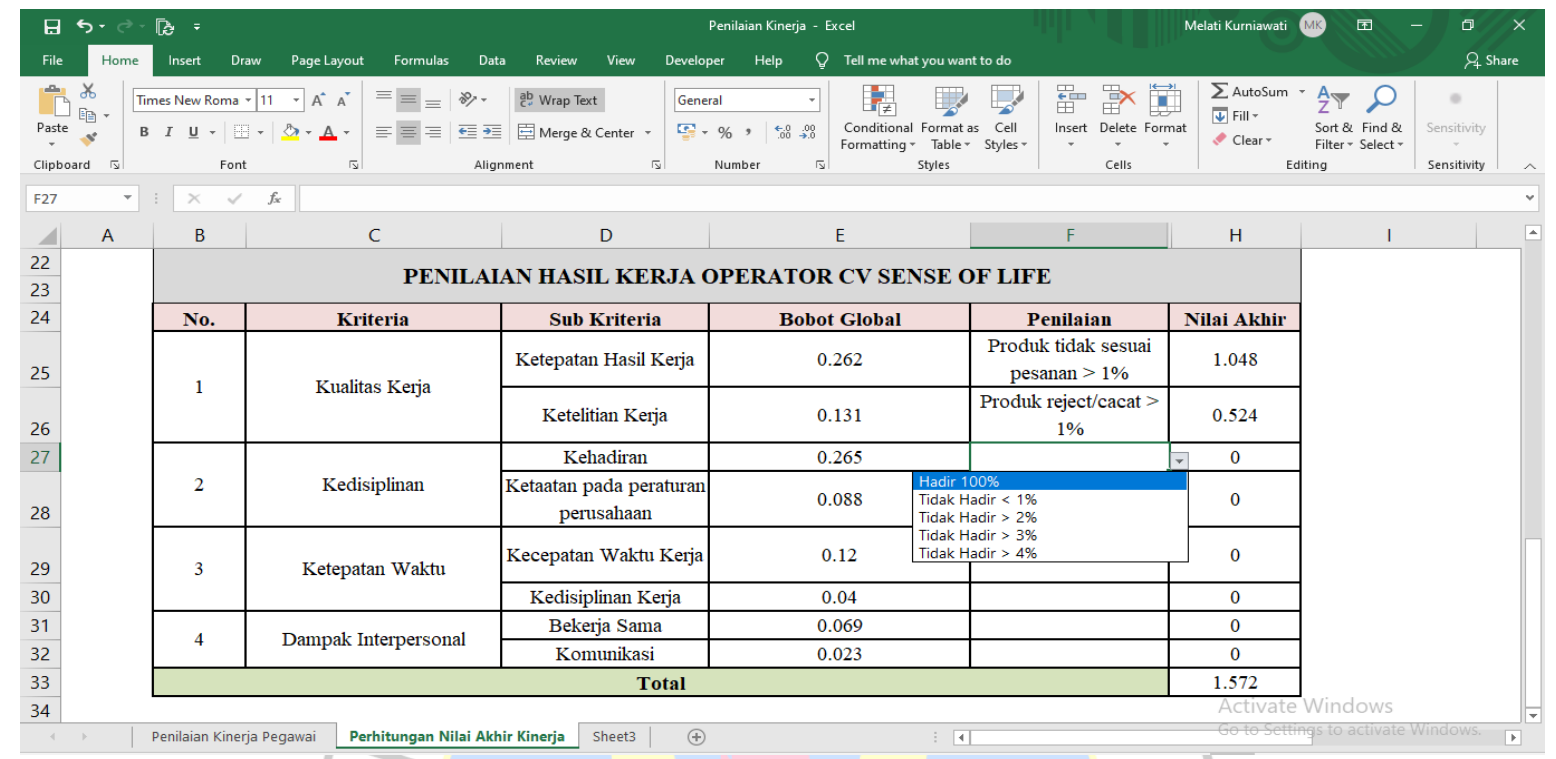

\section{Gambar 2. Pengambilan Data Kinerja Karyawan}

Penilaian kinerja ini digunakan sebagai dasar penentuan kompensasi operator berupa pembayaran insentif. Besaran insentif yang diberikan kepada operator didapat dari hasil brainstorming antara tim pengabdian dan pemimpin perusahaan. Outline yang yang dibicarakan adalah mekanisme penilaian kinerja, kesanggupan besaran pembayaran insentif untuk operator, dan sistem pembayarannya.

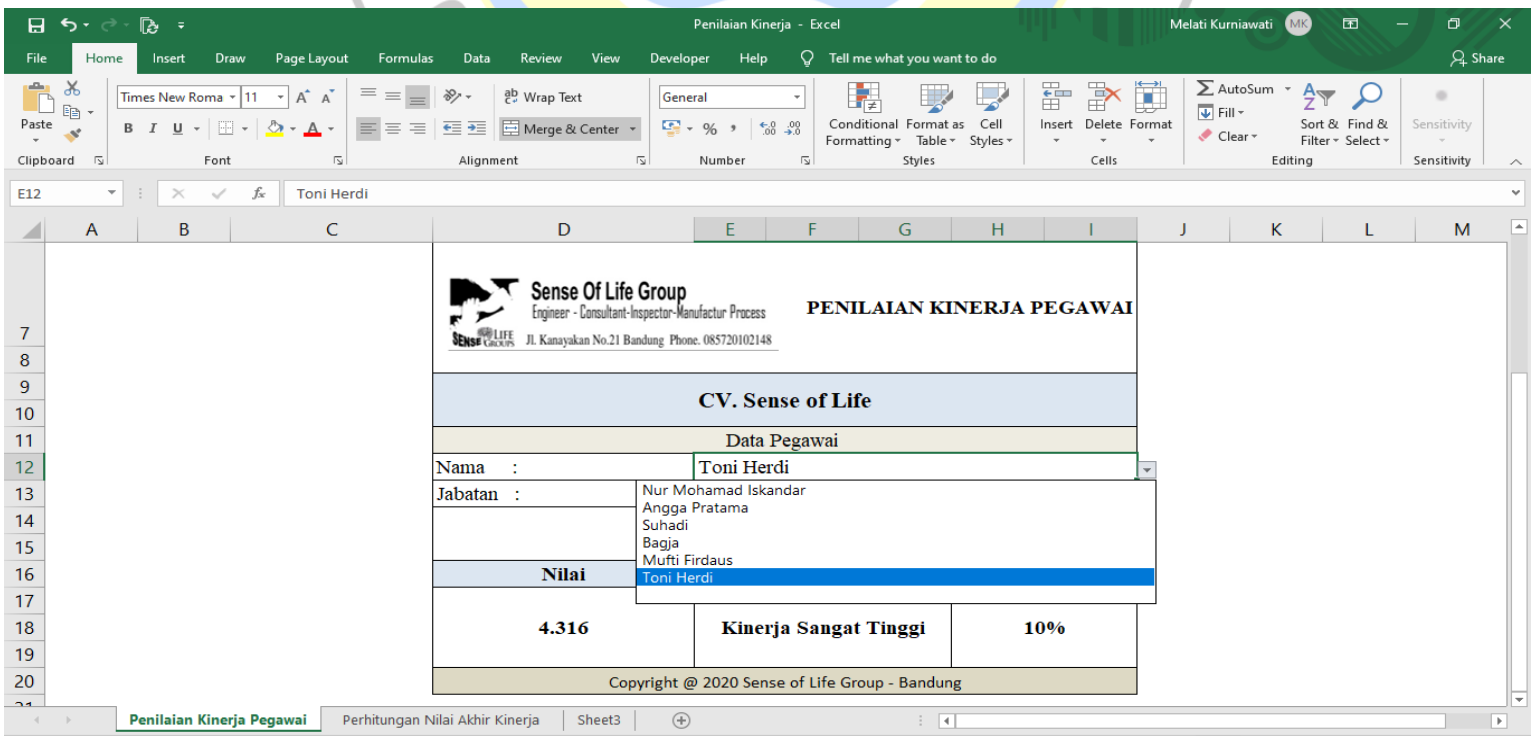

\section{Gambar 3. Visualisasi Penilaian Kinerja dan Insentif Operator}

Hasil diskusi dirumuskan bahwa penilaian akan dilakukan oleh pimpinan perusahaan dan dilakukan per periode ( 6 bulan). Sistem pemberian insentif berdasarkan urutan hasil kinerja dari yang 
tertinggi hingga yang terendah. Rank pertama mendapatkan insentif $10 \%$ dari gaji pokok/bulan, peringkat ke-2 mendapatkan 9\%, peringkat ke-3 mendapatkan $8 \%$, peringkat ke-4 mendapatkan $7 \%$, peringkat ke-5 mendapatkan $6 \%$, peringkat ke-6 mendapatkan $5 \%$. Sistem pembayaran insentif diberikan setiap bulan besamaan dengan pemberian gaji pokok dan tunjangan lainnya. Visualisasi hasil penilaian kinerja dan insentif yang diperoleh operator dapat dilihat pada Gambar 3. Rekapitulasi hasil dapat dilihat pada Gambar 4.

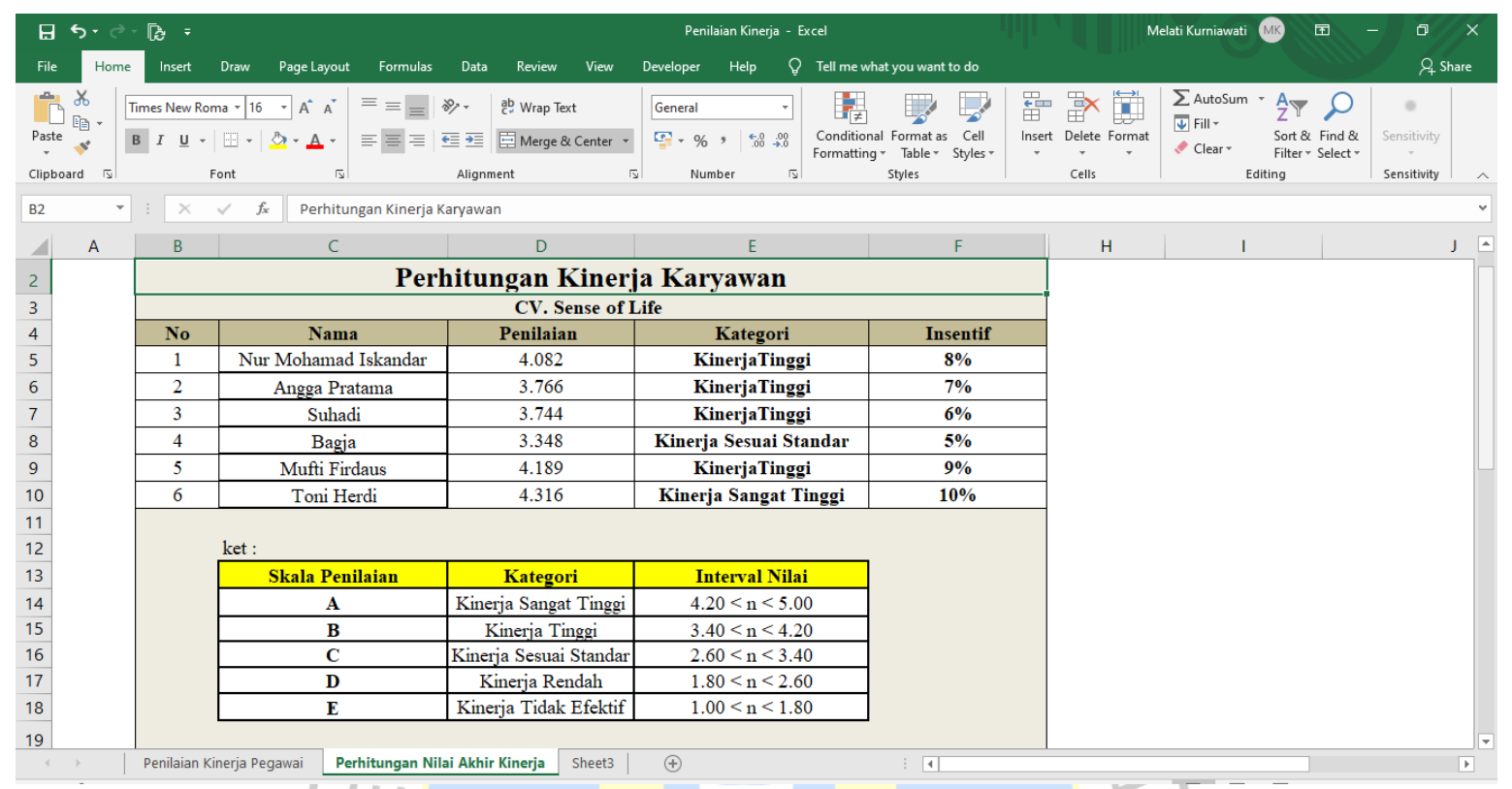

Gambar 4. Rekapitulasi Hasil Perhitungan Kinerja dan Insentif

\section{Kesimpulan}

Sistem penilaian kinerja yang diterapkan pada kegiatan pengabdian ini berupa form yang berisi indikator/kriteria dan sub kriteria yang telah dibobotkan terlebih dahulu dengan metode AHP. Variabel yang digunakan dalam pengukuran adalah kualitas kerja, kedisiplinan, ketepatan waktu dan dampak interpersonal. Hasil pembobotan dari masing-masing kriteria yaitu kualitas kerja 39,4\%, kedisiplinan 35,3\%, ketepatan waktu 16,1\% dan dampak interpersonal 9,2\%. Insentif diberikan setiap bulan dilihat berdasarkan urutan rangking dari hasil penilaian kinerja.

\section{Daftar Pustaka}

Ahmad S. R. (2002). Sistem Manajemen Kinerja, Jakarta: Gramedia Pustaka Utama

Baharun, H. (2016). Manajemen Kinerja Dalam Meningkatkan Competitive Advantage. Jurnal Ilmu Tarbiyah "At-Tajdid”, 5(2), 243-262.

Hasibuan, M. (2016). Organisasi dan Motivasi (Dasar Peningkatan Produktivitas). Jakarta: PT. Bumi Aksara.

Hasibuan, M. S. (2002). Manajemen Sumber Daya Manusia. Jakarta: Bumi Aksara.

Irawati, R., \& Carollina, D. A. (2017). Analisis Pengaruh Beban Kerja Terhadap Kinerja Karyawan Operator Pada Pt Giken Precision Indonesia. Inovbiz: Jurnal Inovasi Bisnis, 5(1), 51. https://doi.org/10.35314/inovbiz.v5i1.171

Mangkunegara, A. . (2013). Manajemen Sumber Daya Manusia Perusahaan. Bandung: Remaja Rosdakarya.

Moheriono, M. (2009). Pengukuran kinerja berbasis kompetensi. Bogor: Ghalia Indonesia. 
Setiani, B. (2013). Kajian Sumber Daya Manusia Dalam Proses Rekrutmen Tenaga Kerja Di Perusahaan. Jurnal Ilmiah Widya, 1(1), 38-44.

Suhardoyo. (2018). Analisis Implementasi Model Manajemen Kinerja Karyawan Pada Industri Manufacture Garment (Studi Kasus: PT. Tae Young Indah). Cakrawala - Jurnal Humaniora Bina Sarana Informatika, 18(2), 193-198.

Suwati, Y. (2013). Pengaruh Kompensasi Dan Motivasi Kerja Terhadap Kinerja Karyawan Pada Pt. Tunas Hijau Samarinda. EJournal Ilmu Administrasi Bisnis, 1(1), 41-55.

Wijayanto, H. (2019). Dinamika Permasalahan Ketenagakerjaan Dan Pengangguran Di Indonesia. Administratio: Jurnal Ilmiah Administrasi Publik Dan Pembangunan, 10(1), 1-8. https://doi.org/10.23960/administratio.v10i1.82

Yavuz, N. (2004). The Use of Non-Monetary Incentives as A Motivational Tool: A Survey Study in A Public Organization in Turkey. Middle East Technical University.

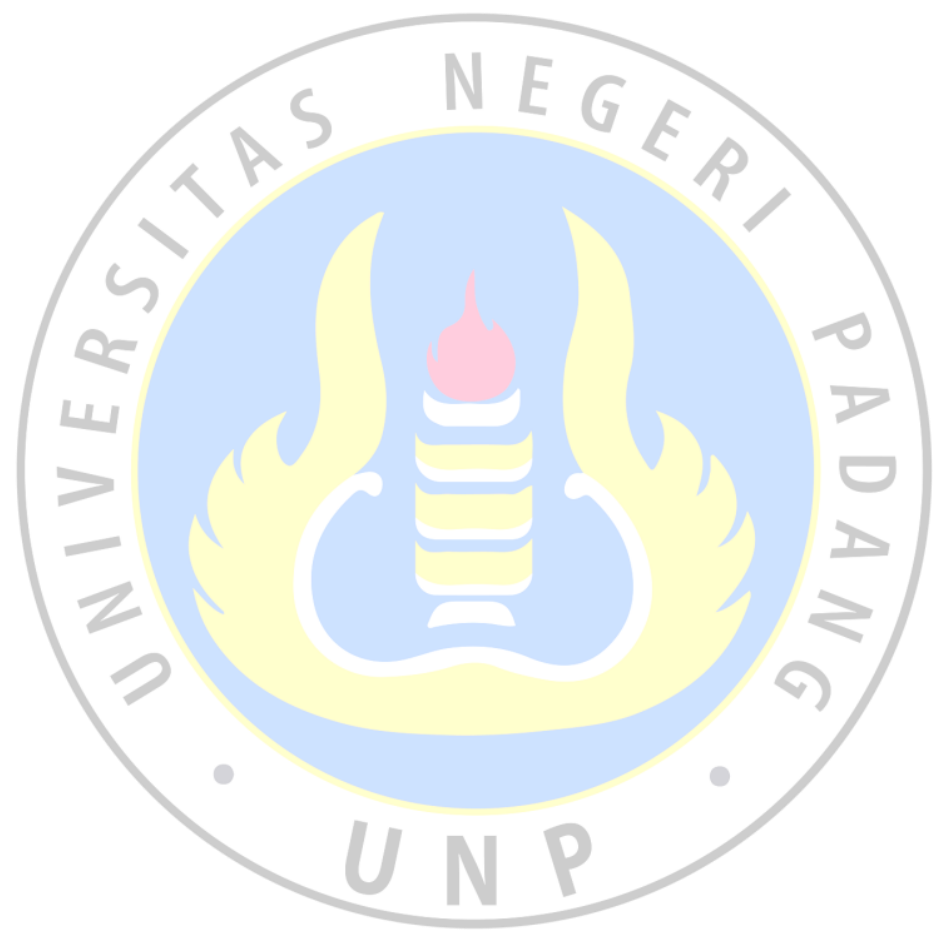

